Teacher Education and Professional Standards of the National Education Association is definitely interested in this problem and is ready to give assistance wherever possible on problems of recruiting better candidates for teachers. There is urgent need for co-operative planning and prompt action.

\title{
WHAT ARE THE GURRENT PROBLEMS IN ACHIEVING BETTER SCHOOL AND COLLEGE RELATIONS?
}

Chairman: C. E. Taylor, Director of Admissions, Kansas Wesleyan University, Salina, Kansas

\section{Discussants:}

M. Curtis Howd, Principal, Burris School, Ball State Teachers College, Muncie, Indiana

Donald L. Oliver, Director of Admissions, Boston University, Boston, Massachusetts

\section{Summary of the presentation made by CLYDE VROMAN}

$\mathrm{I}$

N THIS brief paper let us accept the phrase "better school and college relations" as covering all the functional, co-operative projects and processes planned and carried out by the schools and colleges in all matters which affect students and their educational experiences. Since Mr. Peterson is speaking for the secondary-schools, I shall speak only from the college point of view.

Colleges and universities know that the tidal wave of students will double the demand for college education by 1970 . Individually and by joint action the institutions of higher education are attacking the problem of how the educational needs of youth can be met in these years ahead. In 1951, the American Association of Collegiate Registrars and Admissions Officers established a Committee on High School-College Relations to give careful and extended consideration to this problem. In April, 1955, this Committee published a report in the form of a book, entitled Secondary SchoolCollege Co-operation, An Obligation to Youth, copies of which are available at a small price. This publication defines the common problems in school and college co-operation and particularly shows how the problem should be attacked on the institution, the state, the region, and the national levels. Through the work of this Committee AACRAO prepared itself for the next phase of the attack on the problem, co-operative work with the NASSP.

Clyde Vroman is Director of Admissions in the University of Michigan in Ann Arbor, Michigan. 
On January 13-14, 1956, in Chicago, the AACRAO Committee on High School-College Relations met jointly with the NASSP Committee on School-College Relations to explore the broad subject of school-college relations. Here for the first time there was an official "meeting of the minds" on the national level between school principals and college registrars and admissions officers. The report of this very important meeting is available upon request.

Accordingly, the current problems in school and college relations listed in the balance of this paper are those which have been identified through very extensive study over the last few years.

The main problem in achieving better school and college relations is the lack of systematic and concerted effort by secondary schools and colleges to work together on this problem. Only a minority of colleges have a specific program designed to foster effective understanding and articulation between them and the schools from which they receive students. Colleges have an obligation to develop these relationships and secondary' schools should be willing to devote time and energy to the projects which the colleges organize to aid in the solution of common problems. In addition to the institution-centered projects, we must have co-operative action at the state level. During the last few years various states have initiated school-and-college relations committees, but even yet not more than half of our states have such committees.

Colleges are facing certain major problems as they see the tidal wave of studenis coming toward them. First, the quality standards of American education must not be lowered; if anything, the demands of our society and the decades ahead will acquire a consistent increase in the quality and competencies of college graduates. Second, this objective of quality can be reached if funds are available to provide necessary facilities and faculties. Third, it seems appropriate to encourage differentiation in the nature and roles of various kinds and types of colleges in order to serve effectively the wide variation in interests, abilities, and educational objectives of collegeage students. This means that colleges in general will attempt to select students for whom they have appropriate programs of instruction and who have reasonable probability of success in their chosen programs of study. Here the secondary schools must be brought into the process. This problem of the future of our higher education and the direction which colleges will take in identifying and implementing their roles is receiving top priority by educational leaders. One phase of the problem is, how can we insure that the solutions of the problem on the college level will at the same time be beneficial to secondary schools and their students?

Some of the specific problems which colleges already are facing include the following: Whom shall we admit? Shall we have more selective admissions? How shall we select our students? What shall be the admissions process and when should it be done? What kinds of secondary-school preparation are desirable for our students, and what preparation shall we require? What will be the role of tests and examinations in our ad- 
missions process? What information and records do we want from the secondary schools? How can we get effective and legible transcripts from the schools? How can we procure and make use of the principal's recommendation about students? How can we get more uniformity and meaning in the student's "rank in class?" How can we insure good transition to college life and studies? How can we relate the instructional programs of schools and colleges? How can we help in the education of the gifted? How far should we go in promoting college-level courses in secondary schools and in giving advanced credit to college freshmen? How shall we report student progress and adjustment in college? How can we give schools information on the success of their students in college as compared with students from other schools, and should this be done? How can we achieve better understanding and implement joint projects between school and college counselors and faculties? When is the concept that "every highschool graduate should have a chance to go to college," appropriate and fair to the student? What is a reasonable attrition rate in college?

All these and many more are the specific problems which colleges face as they attempt to provide programs of higher education and, at the same time, to work co-operatively with secondary schools. I am confident that we have educational leaders of good will and ability who can solve these problems effectively. The challenge is to find people who will devote the time and energy to the long and arduous process of finding solutions through co-operative study and actions.

\section{Summary of the presentation made by F. M. PETERSON}

$\mathrm{T}$

HE committee on school-college relations was authorized by the Executive Committee of the National Association of Secondary-School Principals, effective date September 1, 1955. The charge given to the committee was to (a) identify all issues and problems that concern both colleges and secondary schools, especially in the area of the transition of students from secondary schools to college; (b) to study these issues and problems and consider ways and means, if necessary, to improve them to the extent of bringing a better understanding and a greater facility of transition of students from one institution to the other; (c) to identify any new problems and issues as they may develop and make recommendations to the Executive Committee of the NASSP on how such issues and problems can best be resolved.

The first action taken by the committee on school-college relations was to arrange for a joint meeting with the School-College Relations Com: mittee of the American Association of Collegiate Registrars and AdmisIllinois.

F. M. Peterson is Superintendent of the Pekin Community High School in Pekin, 
sions Officers. The joint meeting, held in Chicago on January 13 and 14, 1956, adopted the following agenda:

1. Problems related to increased college enrollments: (a.) increased selectivity in admissions, (b.) changing admissions standard, and (c.) changing admissions requirements

2. Trends toward increased use of the regional and national testing programs and the impact of corporate scholarships such as General Motors, Weyerhauser, Merit Scholarships, state scholarship programs, etc.

3. Articulation of school and college curricula and instructional practices in regards to improved orientation with emphasis on more freedom of choice as a high-school senior, information on budgets of time and money, and better communication between the colleges and secondary schools with a view toward "bridging the gap" with greater ease.

4. Advance standing credit for high-school study.

5. The value and the use of the NASSP Secondary-School Record blanks.

a. Trend to substitute photostats of high-school record cards for transcripts

b. The value of devising a transcript form that could also be used for high-school permanent records.

6. Ways and means of improving contacts between college admissions officers, students and counselors (college days, college nights, visitation days, visual aids, etc.)

The joint discussion of the agenda topics was productive and of great significance. The problems were found to be numerous; however, agreement between the joint committee members seemed to be the rule rather than the exception and disagreements very few indeed. Generally speaking, it was indicated that these problems were due for study over a considerable period of time, and it was significant that the only motion made which ended in action was for a study of the "scholastic record blank." It was also significant that the group voted unanimously to call a second joint meeting at approximately the same time in January 1957 . In the joint sessions, the discussion "ran the gamut" and seemed always to come back to the question of admissions. Members were ever mindful of the "upsurge in enrollments" and came to agree that this increase in enrollment was not merely a "tide" but would result in a continuing "plateau." All members were mindful of the fact that "time is short" and the period critical. Plans must be made now or one must take what comes. Without plans, we must put up with a "make-shift."

It was basic to the thinking of the group that here in America an adequate education is a birthright. Recognition was made of the fact that "education for all" is a social obligation. It was agreed that all educational institutions must do their fair share and not evade the issue by hiding selective admissions. The committee members were not unmindful that some might place the wrong connotation on the word "selective." However, no adequate substitute was found. In the thinking of the joint committee (a) we must all carry our fair share of the increased enrollment and do as well porportionately as we are doing now, (b) we must give our young people 
maximum opportunity for leadership and scholastic confidence. We must co-ordinate the standards of admissions so that students are selected as being best suited to receive the services peculiar to a particular college. These students will also be accepted with the reasonable expectation that the great majority will complete the selected course. The standards of admission should not be so rigorous as to exclude potential leaders and competent students.

As colleges take up their task and make their decisions toward expansion rather than selectivity, it was felt that greater use should be made of the community college with terminal courses as well as preparation for a continuance in another college after the fourteenth grade.

Our program must be an action program. Tools for implementing such a program are as follows:

1. Testing program-This should be pointed in the direction of a reduction in total number of the many tests now used. The direction should also be toward uniform testing.

2. Guidance-(a.) an integral part of education and a two-way street, (b.) closer co-operation by more visitation between secondary schools and college, follow-up reports, and closer co-ordination of standards.

3. Scholarships

a. It appears that secondary schools do not have enough to do with the planning of available scholarships. The thinking also seemed to be that the secondary-school people were more favorably disposed toward college rather than corporate scholarships.

b. College credit for advanced work was indicated; however, the consensus seemed to be in opposition to permitting students from acceptance as college students before completion of their high-school career.

4. It was agreed that a joint committee would work on plans for the revision of the secondary-school record "with a view toward attempting to get more uniform adoption, especially with the stamp of approval coming from AACRAO." It was agreed that the 1957 meeting would be set as the target date for final action.

5. Some discussion was held concerning the possibility of a handbook of good practices for high schools, relating to college days, career days, and other devices of a similar nature.

It was indicated that there is a genuine need for the orientation of highschool students in order to enable them to "bridge the gap" more successfully. Emphasis should also be given to finding better ways of communication between high schools and colleges, especially with a view to a better understanding of the educational and instructional program both in the high school and in college. It was generally indicated, in the discussions, that a national approach was required rather than a state or regional approach.

It was the consenus of the group that the meeting had been carried out along the lines of the charge given by the National Association of Secondary-School Principals. The problems were identified and plans were made for a continuing study with a view toward final solution of the problems and clarification of issues. 